\title{
IMPACT OF PESTICIDES USE ON TRUE SPIDER POPULATION IN TOMATO FARMS IN FAYOUM GOVERNORATE
}

\author{
Ashraf, A. R. Rahil \\ Plant Protection Dept. Fac. of Agric. Fayoum Univ. Egypt.
}

ABSTRACT

Eighteen species of spiders in six families were collected from tomato fields in Fayoum governorate. Population of these spiders reached up to 25 indiv./10 plants at the end of season (Nov.) in plots with no chemical treatment. The correlation between spiders population and Nesidicoris tenuis Reut (Hemiptera) the main prey in untreated plots was significantly negative. Admiral (pyriproxyfen), Actacron (profenofos) and Pilarmate (methomyl), the three pesticides recommended for use against tomato pests caused highly significant reduction in spider populations. Pilarmate was the highest toxic to spiders followed by Actacron and the least was Admiral with reduction percentages of 85,83 and $70 \%$, respectively.

Key words: True spider, tomato, Nesidicoris tenuis, control, Admiral, Actacron, Pilarmate.

\section{INTRODUCTION}

Spiders are potential field predators of various pests. A diverse stable assemblage of spiders might keep densities of these pests at low levels. As pointed out by Darlene et al., 2003, spiders exhibit the ability to lower and stabilize pest populations; i.e. act as excellent biological pest management candidates.

Nevertheless, the continued use of pesticides often also lowers spider populations (Feber et al. 1998; Huusela-Veistola 1998; Yardim and Edwards 1998; Bogya and Marko 1999; Holland et al. 2000 and Amalin et al. 2001). Furthermore, spiders are more sensitive than many pests to some pesticides such as synthetic pyrethroides, organophosphates and carbamates (Brown et al. 1983; Birnie et al. 1998; Huusela-Veistola 1998; Yardim and Edwards 1998; Marc et al. 1999; Holland et al. 2000 and Tanaka et al. 2000).

Nevertheless, tomato production in Egypt relies almost exclusively on the use of synthetic pesticides of which Admiral, Actacron and Pilarmate are recommended. Consequently, the present study was designed to evaluate the impact of these insecticides on the spider assemblages in tomato farms in Fayoum as one of the important vegetable cultivated in about 30,000 feddans during 2005 in this governorate. Clarifying the real effect of insecticides on these natural enemies is essential for better integrated pest management programs.

\section{MATERIALS AND METHODS}

Tomato, Lycopersicom esculentum Mill variety Shifa $F_{1}$ was planted on the $1^{\text {st }}$ of June 2005 and seedlings were transplanted on July $1^{\text {st }}$ in an area of $1 / 4$ feddan divided into 16 equal plots. Two rows were left without plants between plots to avoid cross contamination. All normal agricultural practices were followed. In a randomized block design for 3 pesticide treatments and untreated control, Admiral (10\% EC), Actacron ( $72 \%$ SP) and Pilarmate (90\% SP) were used at the recommended rates, $50 \mathrm{ml}, 125 \mathrm{ml}$ and $50 \mathrm{gm} / 100$ liter water,

Fayoum J. Agric. Res. \& Dev., Vol.20, No.1, January, 2006 
respectively. Spraying was carried out 15 days after transplantation and repeated every 7 days for 10 weeks.

Collections and counts of true spiders and pests started one week after first application and continued every week throughout 10 weeks during application and 6 weeks after the last spray. Each count included 50 double strokes with a sweeping net, and also direct count of 10 randomly selected plants.

Specimens of pests were placed in plastic bags while true spiders were preserved in $70 \%$ alcohol in glass vials. Identification of the collected spiders was carried out using the appropriate keys from those given by Denis 1947, Kaston and Kaston 1953, Levy and Amitai 1982, and Breene et al. 1993.

\section{RESULTS AND DISCUSSION}

In the present study, 18 species of spider in 6 families were recorded and shown in table1. According to foraging modes, these spiders fall into the following two groups

A) Web-makers: This group included three families namely; Araneidae, Dictynidae and Theridiidae.

B) Hunting spiders: This group is not web makers and thus may come into direct contact with pesticide sprays. Also three families were found from this group, namely; Miturgidae, Philodromidae and Thomisidae.

Relative Abundance of Spiders (table 2 and Fig.1) :

No spiders were found on July 23, 2005 in all plots. By direct count, spiders began to appear in control plots at a rate of 4 indiv./10 plants on July30 then fluctuated to reach a peak $\left(22 / 10\right.$ plants) in the $3^{\text {rd }}$ week of Sept. Population later fluctuated reaching 19, 12, 23, 22, 10, 20 indiv./10 plants during the weeks that followed. A second peak (25/10 plants) occurred in Nov. 5 , i.e. the number of spiders increased until the end of the season.

Table 1. True spiders collected from tomato farms in Fayoum governorate 2005 season.

\begin{tabular}{|l|l|}
\hline Family & Species \\
\hline Araneidae & Araneus miniatus (Walckenaer) \\
& Eustala anastera (Walckenaer) \\
& Mangora placida (Hentz) \\
& Metazygia wittfeldae (McCook) \\
& Singa pratensis Emerton \\
\hline Dictynidae & Dictyna segregata (Gertsch\& Mulaik) \\
\hline Miturgidae & Chieracanthium jovium (Denis) \\
\hline Philodromidae & Thanatus fabricii Audouin \\
& T. formicinus (Clerck) \\
\hline Theridiidae & Anelosimus aulicus (Koch) \\
& Steatoda triangulosa (Walckenaer) \\
& Theridion murarium Emerton \\
& Th. tepidariorum (Koch) \\
\hline Thomisidae & Misumena asperatus (Hentz) \\
& M. vatia (Clerck) \\
& Misumenops oblongus (Keyserling) \\
& Xysticus elegans Keyserling \\
& X. funestus Keyserling \\
\hline
\end{tabular}

Fayoum J. Agric. Res. \& Dev., Vol.20, No.1, January, 2006 
IMPACT OF PESTICIDES USE ON TRUE SPIDER POPULATION....150

In treated plots the three pesticides caused sharp reduction in spider population, compared with the untreated control plots as shown in table 2. Such reduction was always evident even after pesticides application was stopped. Pilarmate was the most destructive to true spiders followed by Actacron and Admiral with reduction percentages of 85,83 and $70 \%$, respectively. The population of spiders in untreated plots using direct counts was about 3.2, 5.2 and 6.7 folds that found in Admiral, Actacron and Pilarmate treated plots, respectively.

Besides, of the 18 species found in untreated plots (table 1), only 13, 9 and 7 species in Admiral, Actacron and Pilarmate were found in treated plots, respectively. This observation may depend on the foraging mode of spiders, which seems to play an important role in their susceptibility. Most of the disappeared species belonged to the hunter spiders group.

The results (table 2 and fig.1) clearly indicated that the increase in spider populations in treated plots occurred during the last 6 weeks after spray, which represented about 74, 71 and $50 \%$ of the seasonal total number of spiders recorded in Pilarmate, Actacron and Admiral treatments, respectively. This observation indicates the direct impact of pesticides application. Such stress on population was devoid thereafter in 6 weeks.

Results obtained showed that the hunting spiders were more susceptible to the three pesticides than web makers (in their webs). Adimiral (pyriproxfen) is an insect growth regulator and may be considered as relatively selective insecticide. Therefore, it could be adviced to use Admiral at the latent period to control insect pest Admiral is less hazardous to the natural enemies because the repeated applications destroy spider communities and there remains an urgent need for more selective pesticides to allow control of primary pests without the disruption of predator populations.

In this respect, Birnie et al. (1998) mentioned that the organophosphates are highly toxic to spiders and dimethoate sprays resulted in $100 \%$ mortality to the lycosid Trochosa ruricola (De Geer) at concentration below recommended field application rates. Yardim and Edwards (1998) mentioned that carbaryl and endosulfan application reduced $37 \%$ to $91 \%$ in spider populations in tomato agroecosystems in Ohio, USA. Pekar (1999) mentioned that hunting spiders were more susceptible to the pesticides than web makers (in their webs). The dense cribellate and frame webs of Dictyna and Theridion, respectively reduced the mortality caused by permethrin, also Philodromidae are diurnal ambush spider hunting on leaves which are also exposed to direct spray.

Fayoum J. Agric. Res. \& Dev., Vol.20, No.1, January, 2006 

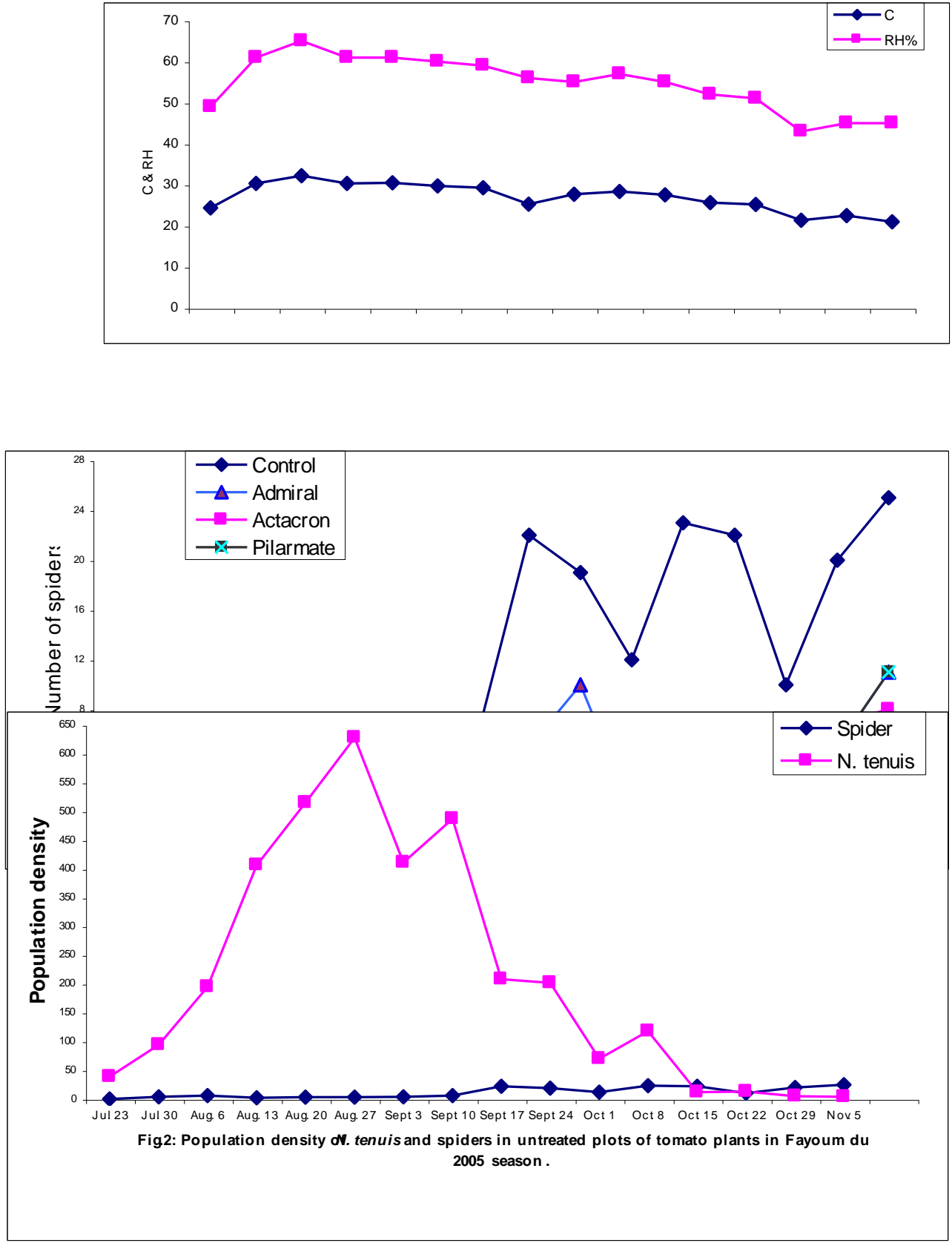

Fayoum J. Agric. Res. \& Dev., Vol.20, No.1, January, 2006 
IMPACT OF PESTICIDES USE ON TRUE SPIDER POPULATION....152

Table 2. Effect of three pesticides on the relative abundance of true spiders associated with tomato plants in Fayoum.

\begin{tabular}{|c|c|c|c|c|c|c|c|c|}
\hline \multirow{3}{*}{$\begin{array}{l}\text { Sampling } \\
\text { Date }\end{array}$} & \multicolumn{8}{|c|}{ Number of spiders in treatment indicated } \\
\hline & \multicolumn{2}{|c|}{ Control } & \multicolumn{2}{|c|}{ Admiral } & \multicolumn{2}{|c|}{ Actacron } & \multicolumn{2}{|c|}{ Pilarmate } \\
\hline & D.C & S.N & $\overline{D . C}$ & S.N & D.C & S.N & D.C & S.N \\
\hline \multicolumn{9}{|c|}{ Pesticide application period } \\
\hline $30 / 7 / 2005$ & 4 & 0 & 0 & 0 & 1 & 0 & 1 & 0 \\
\hline $6 / 8$ & 6 & 1 & 1 & 0 & 1 & 0 & 1 & 0 \\
\hline 13 & 2 & 0 & 1 & 1 & 2 & 0 & 2 & 0 \\
\hline 20 & 3 & 0 & 2 & 0 & 1 & 1 & 2 & 0 \\
\hline 27 & 3 & 2 & 2 & 0 & 0 & 1 & 0 & 0 \\
\hline $3 / 9$ & 4 & 3 & 3 & 0 & 0 & 0 & 0 & 0 \\
\hline 10 & 6 & 5 & 5 & 0 & 0 & 0 & 0 & 1 \\
\hline 17 & 22 & 5 & 5 & 1 & 2 & 0 & 1 & 1 \\
\hline 24 & 19 & 7 & 10 & 1 & 3 & 0 & 0 & 0 \\
\hline \multicolumn{9}{|c|}{ Residual period } \\
\hline $1 / 10$ & 12 & 1 & 0 & 0 & 0 & 1 & 0 & 1 \\
\hline 8 & 23 & 4 & 5 & 1 & 2 & 0 & 1 & 0 \\
\hline 15 & 22 & 4 & 5 & 2 & 3 & 0 & 2 & 0 \\
\hline 22 & 10 & 7 & 2 & 2 & 5 & 1 & 1 & 2 \\
\hline 29 & 20 & 9 & 5 & 2 & 7 & 1 & 5 & 1 \\
\hline $5 / 11$ & 25 & 2 & 11 & 2 & 8 & 0 & 11 & 2 \\
\hline Seasonal Total & 181 & 50 & 57 & 12 & 35 & 5 & 27 & 8 \\
\hline
\end{tabular}

D.C: Direct counts (10 plants)

S.C: Sweeping net (50 strokes)

\section{Impact of Spiders on Tomato Bug Nesidicoris tenuis Population:}

Tomato bug was the main pest on tomato plants during the period of this study. The correlation between $N$. tenuis and true spiders population in untreated plots was estimated to provide information about the expected role of spiders as biocontrol agent in agricultural ecosystems.

As shown in table 3 and fig.2, spiders were recorded from the $4^{\text {th }}$ week of tomato transplantation till the end of the season, the pest / predator population relationship passed through three stages (periods). First, during a period of $8^{\text {th }}$ week, the population density of pest surpassed spiders, as the weekly numbers recorded were 39/0, 94/4, 195/6, 406/2, 515/3, 628/3, 411/4 and 487 pests $/ 6$ predators, respectively. During the $2^{\text {nd }}$ period of four weeks, i.e. until Oct. 8, the number of pest decreased, meanwhile, the number of spiders increased reaching 208/22, 202/19, 70/12 and 118 pests/23 predators, respectively. During the $3^{\text {rd }}$ period last four weeks of the season, the number of spiders collected once again surpass the number of associated pests being $12 / 22,13 / 10,5 / 20$ and 4 pests/25 predators, respectively.

Such relationship indicated that at the beginning of the season predation was ineffective against this pest, perhaps due to a high level of prey population compared to that of predator due to the fact that the pest reproduced several generations compared to only one generation for the predator. In the second stage, the pest declined to moderate numbers whereas the number of associated predators increased than that recorded at the beginning of the season. The role of spiders was evident as potential biological control agent at the end of the

Fayoum J. Agric. Res. \& Dev., Vol.20, No.1, January, 2006 
season where the number of pest reached its lowest level while the number of predators exceeded that of pests. Allover the season, a negative significant correlation was found between the number of prey and predators with $\mathrm{r}=-0.555$.

In conclusion, spiders of several families are commonly found in tomato crop and have been documented as predators of major pests species. On the other hand, the three pesticides, Admiral, Actacron and Pilarmate were harmful to spiders and had more pronounced effect on hunting spiders than that on web maker spiders.

Table 3: Population density of $N$. tenuis and spiders in untreated plots of tomato plants in Fayoum during 2005 season .

\begin{tabular}{|c|c|c|c|c|c|c|c|c|c|c|c|c|c|c|c|c|}
\hline $\begin{array}{l}\text { Sampling } \\
\text { Date }\end{array}$ & 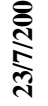 & હે & $\frac{\infty}{b}$ & $\stackrel{\infty}{m}$ & 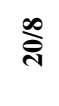 & $\underset{\sim}{\stackrel{\infty}{N}}$ & ભે & $\stackrel{\vartheta}{\varrho}$ & $\stackrel{2}{\underline{I}}$ & ন্ & $\stackrel{\ominus}{\rho}$ & $\stackrel{\ominus}{\stackrel{\infty}{\infty}}$ & $\stackrel{2}{\frac{1}{2}}$ & 을 & 옳 & 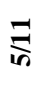 \\
\hline N. tenuis & 39 & 94 & 195 & 406 & 515 & 628 & 411 & 487 & 208 & 202 & 70 & 118 & 12 & 13 & 5 & 4 \\
\hline Spiders & 0 & 4 & 6 & 2 & 3 & 3 & 4 & 6 & 22 & 19 & 12 & 23 & 22 & 10 & 20 & 25 \\
\hline
\end{tabular}

\section{REFERENCES}

Amalin, D.M.; J.E. Pena; R. Mcsorley; H.W. Browning and J.H. Crane (2001). Comparison of different sampling methods and effect of pesticide application on spider populations in lime orchards in South Florida.Environ. Entomol. 30: 1021-1027.

Birnie, L.; K. Shaw; B. Pye and I. Denholm (1998). Considerations with the use of multiple dose bioassays for assessing pesticide effects on nontarget arthropods. Proc., Brighton Crop Prot. Cong.on Pests and Diseases. 16-19 Nov. Brighton, UK, 291-296.

Bogya, S. and V. Marko (1999). Effect of pest management systems on ground dwelling spider assemblages in an apple orchard in Hungary.Agric. Ecosyst. Environ. 73: 7-18.

Breene, R.G.; D.A. Dean; M. Nyffeler and M.B. Edwards (1993). Biology, predation ecology and significance of spiders in Texas cotton ecosystems with a key to the species.Dept. of Ent., Texas A $\alpha$ M Univ., Coll. State; USA 115 pp.

Brown, K.C.; J.H. Lawton and S. Shires (1983). Effects of insecticides on invertebrate predators and their cereal aphid (Hemiptera: Aphidae) prey: laboratory experiments.Environ. Entomol. 12: 1747-1750.

Darlene, M.; F.A. Drummond and R. Alford (2003). Spider predation in Agroecosystems:Can spiders effectively control pest populations. Tech. Bull. 190: 1-32.

Denis, J. F. Z. S. (1947). Results of the Armstrong college expedition to Siwa oasis (Libyan desert) 1935.Bull. Soc. Fouad $1^{\text {st }}$ Entom., xxx1, (17), 85 pp.

Feber, R.E.; J. Bell; P.J. Johnson; L.G. Firbank and D.W. MacDonald (1998). The effects of organic farming on surface-active spider (Araneae) assemblages in wheat in Southern England, UK. J. Arachnol. 26: 190-202. 
IMPACT OF PESTICIDES USE ON TRUE SPIDER POPULATION....154

Holland, J.M.; L. Winder and J.N. Perry (2000). The impact of dimethoate on the spatial distribution of beneficial arthropods in winter wheat.Ann. Appl. Boil. 136: 93-105.

Huusela-Veistola, E. (1998). Effects of perennial grass strips on spiders (Araneae) in cereal fields and impact on pesticide side-effects.J. Appl. Ent. 122: 575-583.

Kaston, B. and E. Kaston (1953). How to know the spiders.W.C. Brown Co., Dubuque, Iowa, USA, $220 \mathrm{pp}$.

Levy, G. and P.Amitai (1982). The comb footed spider genera Theirdion, Achaearanea and Anelosimus of Israel (Araneae: Theridiidae). J. Zool. Lond., 196: 81-131.

Marc, P.; A. Canard and F. Ysnel (1999). Spiders (Araneae) useful for pest limitation and bioindication.Agric., Ecosyst. Environ. 74: 229-273.

Pekar, S. (1999). Foraging mode:a factor affecting the susceptibility of spiders (Araneae) to insecticide applications.Pestic. Sci. 55: 1077-1082.

Tanaka, K.; S. Endo and H. Kazano (2000). Toxicity of insecticides to predators of rice planthoppers: Spiders, the mired bug and the dryinid wasp. Appl. Entomol. Zool. 35: 177-187.

Yardim, E. N. and C. A. Edwards (1998). The influence of chemical management of pests, diseases and weeds on pest and predatory arthropods associated with tomatoes. Agric.Ecosyst. Environ. 70: 3148.

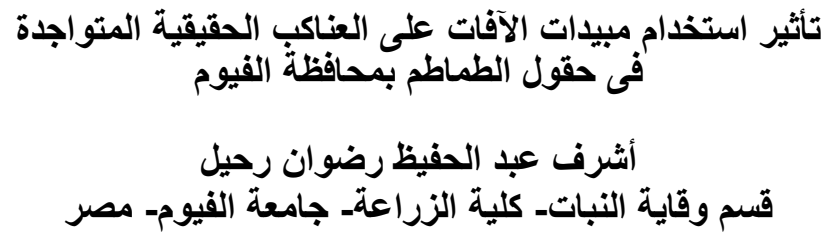

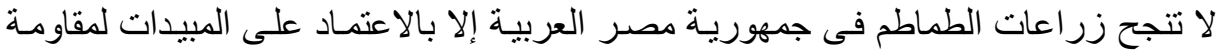

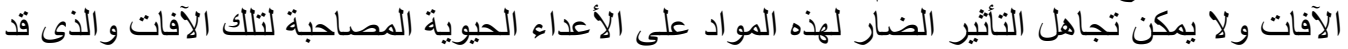

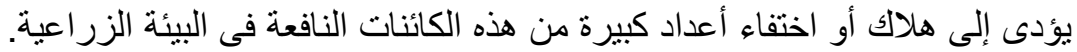

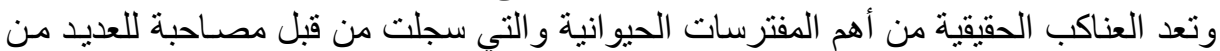

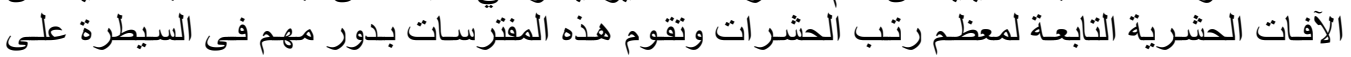

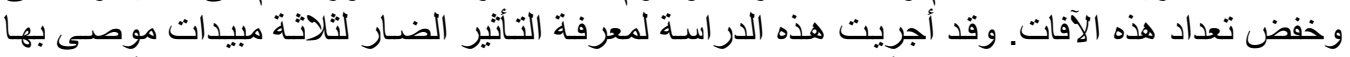

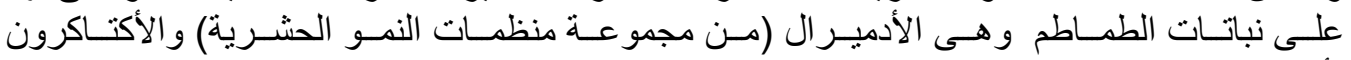

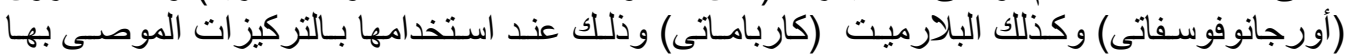

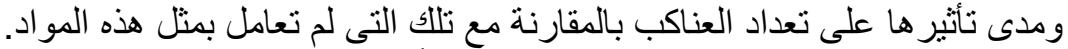

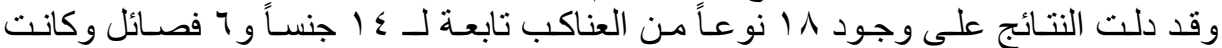

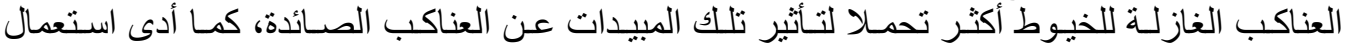

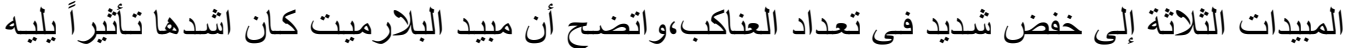

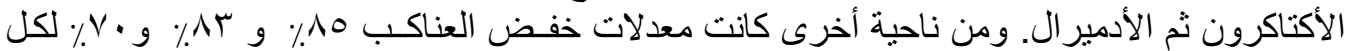

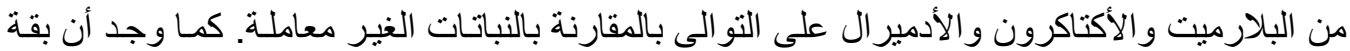

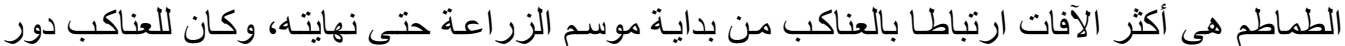
حيوى فى خفض تعدادها فى تجربة المقار الربارنة.

Fayoum J. Agric. Res. \& Dev., Vol.20, No.1, January, 2006 